\title{
Medidas da dinâmica respiratória em crianças de quatro a dez $\operatorname{anos}^{* * * * *}$
}

\author{
Respiratory dynamics measurements in children with four to ten years \\ of age
}

\author{
Eliana Maria Gradim Fabron* \\ Gisele Rodrigues dos Santos** \\ Sadao Omote*** \\ Gleici Castro Perdoná****
}

* Fonoaudióloga. Professora Doutora do Departamento de Fonoaudiologia da Universidade Estadual Paulista Marília. Faculdade de Filosofia e Ciências da Universidade Estadual Paulista - Marília. Endereço para correspondência: Rua Antônio Rossini, 55 - Marília - SP - CEP 17513-380 (elianaf@marilia.unesp.br).

**Fonoaudióloga do Núcleo de Atenção Integrada à Saúde da Criança Prefeitura Municipal de Itapetininga (SP).

***Psicólogo. Professor Titular do Departamento de Educação Especial da Faculdade de Filosofia e Ciências da Universidade Estadual Paulista Marília.

****Estatítica. Mestre em Estatística. Professora Colaboradora da Fundação de Apoio ao Ensino, Pesquisa e Assistência do Departamento de Medicina Social da Faculdade de Medicina de Ribeirão Preto Universidade de São Paulo.

*****Trabalho Realizado na Faculdade de Filosofia e Ciências da Universidade Estadual Paulista - Marília

Artigo de Pesquisa

Artigo Submetido a Avaliação por Pares

Conflito de Interesse: não

Recebido em: 21.06.2005.

Revisado em: 14.12.2005; 12.09.2006; 16.11.2006.

Aceito para Publicação em 16.11.2006.

\section{Abstract}

Background: respiratory dynamics measurements are frequently used in the speech-language pathology practice, but few are the scientific data for children. Aim: to study the respiratory dynamics in children with nasal breathing. Method: the study was performed with a stratified random sample of 106 nasal breathing children, male and female, from schools of the city of Marília-SP, with ages between four and ten years. The following measurements were obtained: vital capacity (VC) in both standing and sitting positions, with and without nasal occlusion; maximum phonation time (MPT) of sustained vowels and consonants and also of speech when counting numbers. Results: the mean values for VC in the standing position with and without nasal occlusion were of $1515.56 \mathrm{ml}$ and $1538.67 \mathrm{ml}$ respectively and for the sitting position of $1524 \mathrm{ml}$ and 1539.15ml respectively. MPT of vowels in seconds were: $/ \mathrm{a} /=8.32$, $/ \mathrm{i} /=8.61$ and $/ \mathrm{u} /=8.42$; of consonants: $/ \mathrm{s} /=6.64$ and $/ \mathrm{z} /=7.65$; and when counting numbers: 7.76. It was observed that the mean values of these measurements progressively increased according to age. There was a statistically significant difference $(\mathrm{p}<0.05)$ not only for the MPT of vowels but also for the MPT of consonants in older children, i.e. between 4 and 10 year olds, 4 and 9 year olds and 4 and 8 year olds. There was no significant statistical difference for the VC values in consecutive age groups. There was a strong association between VC and the child's physical development. Conclusion: this study presented respiratory dynamics measurements in children that can be used for the speech-language diagnosis and therapy. Other studies should be developed in order to bring additional information on the subject.

Key Words: Vital Capacity; Phonation; Respiration.

\section{Resumo}

Tema: medidas da dinâmica respiratória são freqüentemente utilizadas na clínica fonoaudiológica, mas poucos são os dados científicos destas na população infantil. Objetivo: estudar a dinâmica respiratória entre crianças que respiram pelo modo nasal. Metodo: o estudo foi realizado com uma amostra aleatória estratificada de 106 crianças respiradoras nasais de escolas da cidade de Marília / SP, entre quatro e dez anos de ambos os sexos. Foram realizadas as medidas de capacidade vital (CV), nas posições em pé e sentada, com e sem oclusão nasal; de tempo máximo de fonação (TMF) de vogais e consoantes sustentadas, além de fala em seqüência com a contagem de números. Resultados: a medida média da CV na posição em pé com e sem oclusão nasal foi 1515,56 ml e 1538,67 ml respectivamente e na posição sentada, $1524 \mathrm{ml}$ e 1539,15 ml respectivamente; o TMF das vogais em segundos foi: /a/ = 8,32 , /i/ = 8,61 e /u/ 8,42; o de consoantes foi: /s/ = 6,64 e /z/ = 7,65 e o de seqüência de números foi de 7,76 segundos. Resultados: observou-se que o tempo médio destas medidas aumentou progressivamente conforme as faixas etárias. Tanto para o TMF das vogais como, para o das consoantes, houve diferença estatística significante $(\mathrm{p}<0,05)$ nas idades mais distantes, ou seja, entre quatro e dez anos, quatro e nove, e quatro e oito anos. Em faixas etárias consecutivas não houve diferença estatística significante nos valores de CV. Houve forte associação entre a CV e o crescimento físico da criança. Conclusão: esse estudo mostrou medidas de dinâmica respiratória em crianças que podem ser úteis no diagnóstico e terapia fonoaudiológica. Outras pesquisas deveriam ser desenvolvidas para adicionais informações sobre o assunto.

Palavras-Chave: Capacidade Vital; Fonação; Respiração.

Referenciar este material como:

$\Omega$ FABRON, E. M. G.; SANTOS, G. R. dos; OMOTE, S.; PERDONÁ, G. C. Respiratory dynamics measurements in children with four to ten years of age (original title: $\sum 3$ Medidas da dinâmica respiratória em crianças de quatro a dez anos). Pró-Fono Revista de Atualização Científica, Barueri (SP), v. 18, n. 3, p. 313-322, set.- dez. 2006. 


\section{Introduction}

In the speech-language pathology field, the respiratory dynamics aims at verifying the individual's respiratory capacity, the glottal efficiency and the use of the air breathed during the phonation. Such measures are widely spread as part of several speech-language evaluation protocols, however, there are only a few normative data that can support these evaluations' findings and also the researches (Behlau et al, 2005; Stemple et al, 2000).

Researches with all these measures in children are commonly found in the literature. There are isolated data about sustained phonation time, about vital capacity (VC), and a few about the simple phonic quotient (SPQ).

The pulmonary function is usually measured by the VC, that is the amount of air that can be exhaled from the lungs after a maximum inspiration (Zemlin, 2000). The Spirometry Consensus (SOCIEDADE...,1996) listed 10 factors that interfere in the pulmonary function; the ones with greater influence are sex, height and age, in this order. The sex responds for $30 \%$ of the pulmonary variation; the pulmonary volumes are greater in male. Tomalak et al (2002) and Domènech-Clar et al (2003) also observed higher measures in male. The height, according to the Consensus (SOCIEDADE...,1996), is the factor that influences the most the VC in children.

Enright et al (2000) obtained spirometric measures of 4000 children from public schools for three consecutive years. They found a significant influence of age, sex, ethnics, height, and clinical status of the participants. Pérez-Padilla et al (2003b), in a longitudinal study, observed that the technicians and the children training, as well as the better interaction between them, contributes for an increase in the spirometry quality and for the obtaining of better performance levels.

Several studies relate the VC measures of subjects with different age groups, height, thoracic cage size and weight (Behlau et al, 2005; Subbarao et al, 2004; Pérez-padilla et al, 2003a; Torres et al, 2003; Rappaport et al, 2002; Huang et al, 2001; Hernando et al, 2000; Vijayan et al, 2000; Zemlin, 2000; Dugdale; Moeri, 1968). The measures found in these studies vary from $1000 \mathrm{ml}$ for smaller children to $3420 \mathrm{ml}$ for bigger ones. There is a strong correlation between pulmonary function measures and the evaluated subject's height (Eigen et al, 2001; Zapletal; Chalupová, 2003; Agaba et al, 2003).
In the standard measures table of the spirometer FAMI-ITÁ $^{\mathrm{o}}$, the VC is $1400 \mathrm{ml}$ for 9 years old in both sexes, and $1650 \mathrm{ml}$ in male and $1500 \mathrm{ml}$ in female, for 10 years old. Concerning the height, the VC values for male and female are 2350 and $2200 \mathrm{ml}$ for $150 \mathrm{~cm}$ height and 2900 and $2600 \mathrm{ml}$ for $160 \mathrm{~cm}$.

As for vowels, consonant and sequential phonation time measures, most of the bibliographic review mentions adults' measures only.

Hersan (2003) referred that there is a clear relation between the increase of the maximum phonation time (MPT) and the child's age, and that these values tend to follow the numeric value of the child's age until puberty.

The MPT of vowels and consonants presented in the literature vary between 8,8 and $19 \mathrm{sec}$. (Wilson, 1993). In the majority of the studies of a Wilson's (1993) bibliographic review, the MPT is higher for boys.

Rockenbach and Feijó (2000) studied 71 children from 6 to 10 years old and observed the following MPT values for /a/, /i/ and /u/, in seconds: 10,$44 ; 11,22$ and 10,09 for girls and 9,90; 10,69 and 10,19 for boys aging 6,7 and 8 years old; and from 9 to 10 years old, 11,$50 ; 12,67$ and 11,47 for girls and 12,64; 14,09 and 13,67 for boys.

Concerning the MPT of the consonants /s/ and /z/, according to Behlau et al (2005), the /s/ phonation allows to evaluate the individual's capacity to control the pulmonary air support, and since there isn't vocal chords vibration in its production, it is possible to evaluate the frictional source of the sound. In the phonation of $/ \mathrm{z} /$, besides the frictional source evaluation, it is possible to evaluate the glottal source once during its production there is the participation of the laryngeal vibration.

In Frey (1978, apud Wilson, 1993), the MPT of the consonants /s/ and /z/, in seconds, were respectively: for 3 to 4,8 years old, 3,7 and 4,15; for 5,3 to 6,6 years, 4,56 and 5,31; for 3 to 6 years, 4,07 and 4,71 .

The values found by Tait et al (1980) for /s/ and /z/, in seconds, were respectively: for 5 years, 8, 13 and 9,47 ; for 7 years, 9,79 and 13,40 ; for 9 years 15,80 and 17,20; and from 5 to 9 years 12,06 and 13,95 .

In Rockenbach and Feijó's (2000) study, the MPT measures of $/ \mathrm{s} /$ and $/ \mathrm{z} /$ in seconds, for the ages between 6 and 8 years were respectively for girls, 8,38 and 9,42; for boys, 7,17 and 7,91. For 
girls from 9 to 10 years old, 10,91 and 11,51sec. and for boys, 14,4 and 15,2 sec. The mean ratio between the MPTs of /s/ and/z/ was 0,90, with no expressive difference between sex, age group, height and socio-economic level.

Behlau et al (2005) affirmed that a normal adult speaker sustains the phonemes /s/ and /z/ for approximately the same time, resulting in the ratio s/z equals 1.

In the specialized literature no references were found about the expected values for sequenced phonation time in children, nevertheless, it is affirmed that such measure should be closer to the MPTs, and one way to perform the task is counting numbers.

Concerning the simple (SPQ) and composed phonic quotient (CPQ), Shigemori (1977) studied school children and found the following values for male and female, respectively: in the first grades from 77 to $232 \mathrm{ml} / \mathrm{sec}$ and from 63 to $226 \mathrm{ml} / \mathrm{sec}$; in the third grades from 107 to $235 \mathrm{ml} / \mathrm{sec}$ and from 117 to $270 \mathrm{ml} / \mathrm{sec}$; and in the fifth grades from 114 to $244 \mathrm{ml} / \mathrm{sec}$ for boys and from 116 to $274 \mathrm{ml} / \mathrm{sec}$ for girls.

Brazilian studies of this nature, with the national clinical reality, are important in order to offer standardized measures for the diagnostic and the therapeutic process of phono-articulation disorders.

The purpose of this paper is to study the respiratory dynamics of nasal breathing children through tasks that raise data on the respiratory capacity and on the use of the inhaled air during the phonation.

\section{Method}

The methodology of this research was approved by the Research Ethics Committee (CEP) of the Paulista State University, Marília Campus, according to protocol 1559/2002. Parents of all children involved in the research agreed with the performance of the tests and the publication of the results according to the Resolution 196/96 (BRASIL. Resolution MS/CNS/CNEP n 196/96 from 10th of October 1996. Approves guide lines and regulating norms of researches involving human beings. Brasília, 1996. 24p.).

The sample consisted of 106 nasal breathing children ranging in age from 4 to 10 years, being thirteen of 04 years, thirteen of 05 years, eighteen of 06 years, fourteen of 07 years, fifteen of 08 years, fifteen of 09 years and eighteen of 10 years. Concerning the sex, 42 subjects were male and 64 female. Children attended Child Municipal Education Schools (EMEIs), Fundamental Municipal Schools (EMEFs) and Fundamental State Schools (EEEFs), from Marília city/SP.

A protocol was designed for the registration of the respiratory behavior of children. This protocol included the following measures: a) VC (in ml), with the following collecting ways of measure: standing with nasal occlusion (CVPCO) and without nasal occlusion (CVPSO); and sitting with nasal occlusion (CVSCO) and without nasal occlusion (CVSSO); b) MPT of the vowels "a", "i" and "u", of the consonants "s" and " $\mathrm{z}$ " and of counting numbers (in seconds); c) height (in cm). The FAMIITÁ $^{\text {Oे }}$ spirometer was used to obtain the VC measures of the subjects; a chronometer, for consonant and vowels phonation time measures, and a metric tape for the height measure.

After the authorization of the Municipal Education Secretary and the Teaching Board of Marília city, the sample selection procedure was started. Following, the number of children between four to ten years old attending EMEIs, EMEFs and EEEFs of Marília city was surveyed; the schools and classes where data would be collected were randomly selected. Three EMEIs, two EMEFs and one EEEF were drafted, taking into account their occurrence in Marília city, totalizing six schools. The following classes took part in the raffle: Pré I, Pré II and Pré III (in the EMEIs) and from $1^{\text {st }}$ to $4^{\text {th }}$ grades (in the EMEFs and EEEF). One class of each grade and ten students per class were selected randomly, admitting the hypothesis that some of the students would not match the requested profile.

Next, a letter explaining the research and the tests that would be used, an authorization and a parental questionnaire were sent to the parents of all students of the selected classes. The questionnaire aimed at collecting information regarding the respiratory behavior of children that could suggest the nasal breathing mode and other aspects necessary to guarantee the respiratory mode, such as sports practice, health aspects and possible speech-language complaints.

The returned questionnaires suggesting possible oral breathers, those presenting pathologies related to the respiratory system and dysphonia symptoms, those whose parents did not authorize the measures collecting, and those with age above the one requested by the research were discarded.

Prior to the respiratory tests, a screening to assure the nasal breathing was conducted through the observation of the child's respiratory mode 
during certain activities. Children were observed during a drawing activity, during the tests instruction time and during the escorting from their classrooms to the data collecting room. The nasal breathing was confirmed when children maintained a closed mouth posture during the mentioned periods. The data obtained were registered in the protocol about the child's respiratory behavior.

Children were told to perform a deep inspiration followed by a deep exhalation in order for the $\mathrm{VC}$ to be collected with the dry spirometer. The tubes used were changed and cleaned at each new evaluation and the mouthpiece was not reused. These measures were collected with the child standing up with nasal occlusion (CVPCO) and without nasal occlusion (CVPSO), and with the child sitting down with nasal occlusion (CVSCO) and without occlusion (CVSSO).

In order to collect the maximum phonation time of the vowels "a", " $i$ " and "u", and the consonants "s" and "z", children were requested to inhale deeply and sustain the vowels and consonants phonation for the longest time possible. For the counting numbers, children should inhale and count the numbers until when possible. All measures were taken with a chronometer and performed three times, being considered the one with the highest value. The height of the child was measured with the child barefoot. Then, the SPQ and the CPQ $(\mathrm{ml} / \mathrm{sec})$ were calculated. All the procedure took part in the school environment.

Methods of simple linear regression were used for the statistical analysis of the association between the Vital Capacity standing up with nasal occlusion (CVPCO) and height, and the variance analysis was used in the comparison of averages of $\mathrm{VC}$, age and sex, and in the comparison of the vowels MPT. The considered significance (p) was $5 \%$ in all analysis. The software SAS was used.

\section{Results}

The average height of the subjects (in $\mathrm{cm}$ ), according to the age group, was: 112,7 for 04 years; 115,5 for 05 years; 120,0 for 06 years; 127,0 for 07 years; 135,6 for 08 years; 141,4 for 09 years and 145,9 for 10 years.

Concerning the $\mathrm{VC}$ measures, the mean values found are observed in table 1 .

The average $\mathrm{VC}$ increased, in the different ways of the test, according to the age increase. This increase is more evident when the age group $\mathrm{VC}$ averages are more distant from one another. In consecutive age groups there was no significant statistical difference among the $\mathrm{VC}$ values, indicating that although there is an increase of the $\mathrm{VC}$ with the age increase, it is better observed when comparing the averages of distant ages. There was no significant statistical difference between the different ways of $\mathrm{VC}$ testing $(\mathrm{p}=0,05)$.

There wasn't an effect of the sex upon the VC measures in all its ways, that is, the subjects' sex is not statistically determinant over such measures $(\mathrm{p}=0,31$ for $\mathrm{CVPCO} ; \mathrm{p}=0,13$ for $\mathrm{CVPSO} ; \mathrm{p}=0,15$ for $\mathrm{CVSCO}$ e $\mathrm{p}=0,17$ for CVSSO, with a significance value $\mathrm{p}<0,05$ ).

There was a strong positive linear association $(r=0,95)$ between the height and the VC that can be described as a straight line. Figure 1 presents the estimated straight line adjustment.

The sustained phonation of vowels and consonants of all subjects is observed in Table 2.

A variance analysis was done in order to compare the effect of age on the MPTs of vowels and consonants in both sexes.

For the analyzed vowels there was a significant statistical difference $(p<0,05)$ between the more distant age groups, that is, between 4 and 10 years, 4 and 9 , and 4 and 8 years old. In general, the averages differences between close age groups, were not significant. This fact demonstrates that with the age increase, the child acquires longer time of sustained phonation of vowels /a/, /i/ and /u/. The same can be affirmed for the consonants /s/ and $/ z /$, in which the statistical difference occurred between the average measures of age groups from 4 to 6 years old compared to the age groups from 8 to 10 years old. The similarity between the statistical findings for vowels and consonants indicated that the child maintains the same behavior in the production of these sounds and that both of them (vowels and consonants) are influenced by the age increase.

As regards to the subjects' sex, there was no effect on the MPTs of the analyzed vowels and consonants, once the difference between the averages was not significant in any case $(p>0,05)$.

The MPT measures were compared to the average height of the subjects at each age group and the table below shows these related values.

This table shows that either the height of the subjects as the MPT and the counting of numbers increased with the age increase. Although the increase of the phonation time of phonemes and of the counting of numbers had occurred disorderly, it's possible to affirm that as the child gets older and higher, he/she acquires longer phonation times and counting numbers time. 
The ratio between the MPT averages of consonants $/ \mathrm{s} /$ and $/ \mathrm{z} /$ according to the age varied from 0,83 (for 9 and 10 years) and 0,93 (for 4 and 8 years), as illustrates table 4 .

The average sustaining time of a sequence of numbers presented by the subjects corresponded to 7,61 seconds.
The SPQ and the CPQ were calculated for each age group, as shows table 5 .

The ratio SPQ/CPQ evidenced a proximity between the values of both measures, since it varied from 0,90 (in the age group of 7 years) to 1,08 (in the age group of 9 years).

TABLE 1. Average measures and Standard deviation at the different VC ways, according to the age*.

\begin{tabular}{c|cc|cc|cc|cc}
\hline \multirow{2}{*}{ AGE } & \multicolumn{2}{|c|}{ CVPCO } & \multicolumn{2}{c|}{ CVPSO } & \multicolumn{2}{c|}{ CVSCO } & \multicolumn{2}{c}{ CVSSO } \\
\cline { 2 - 8 } & Average & SD & Average & SD & Average & SD & Average & SD \\
\hline 4 & 973,07 & 238,58 & 969,23 & 217,50 & 980,76 & 152,12 & 973,08 & 189,97 \\
5 & 1146,15 & 344,58 & 1142,30 & 318,75 & 1073,08 & 346,78 & 1096,15 & 346,78 \\
6 & 1211,11 & 244,68 & 1233,33 & 188,65 & 1227,78 & 265,25 & 1283,33 & 191,74 \\
7 & 1410 & 347,06 & 1392,86 & 388,21 & 1442,86 & 341,85 & 1453,57 & 343,88 \\
8 & 1643,33 & 277,02 & 1666,67 & 289,49 & 1626,67 & 301,11 & 1620 & 330,47 \\
9 & 1986,67 & 323,19 & 2016,67 & 349,31 & 1990 & 314,07 & 1986,67 & 332,45 \\
10 & 2061,11 & 324,28 & 2150 & 378,85 & 2127,78 & 352,81 & 2150 & 374,95 \\
TOTAL & 1490,20 & 299,91 & 1510,15 & 304,39 & 1495,56 & 296,28 & 1508,97 & 301,46 \\
\hline
\end{tabular}

* VC in ml; age in years. CVPCO = vital capacity standing with nasal occlusion; CVPSO = vital capacity standing without nasal occlusion; CVSCO = vital capacity sitting with nasal occlusion; CVSSO $=$ vital capacity sitting without nasal occlusion.

FIGURE 1. Linear regression of CVPCO related with height*.

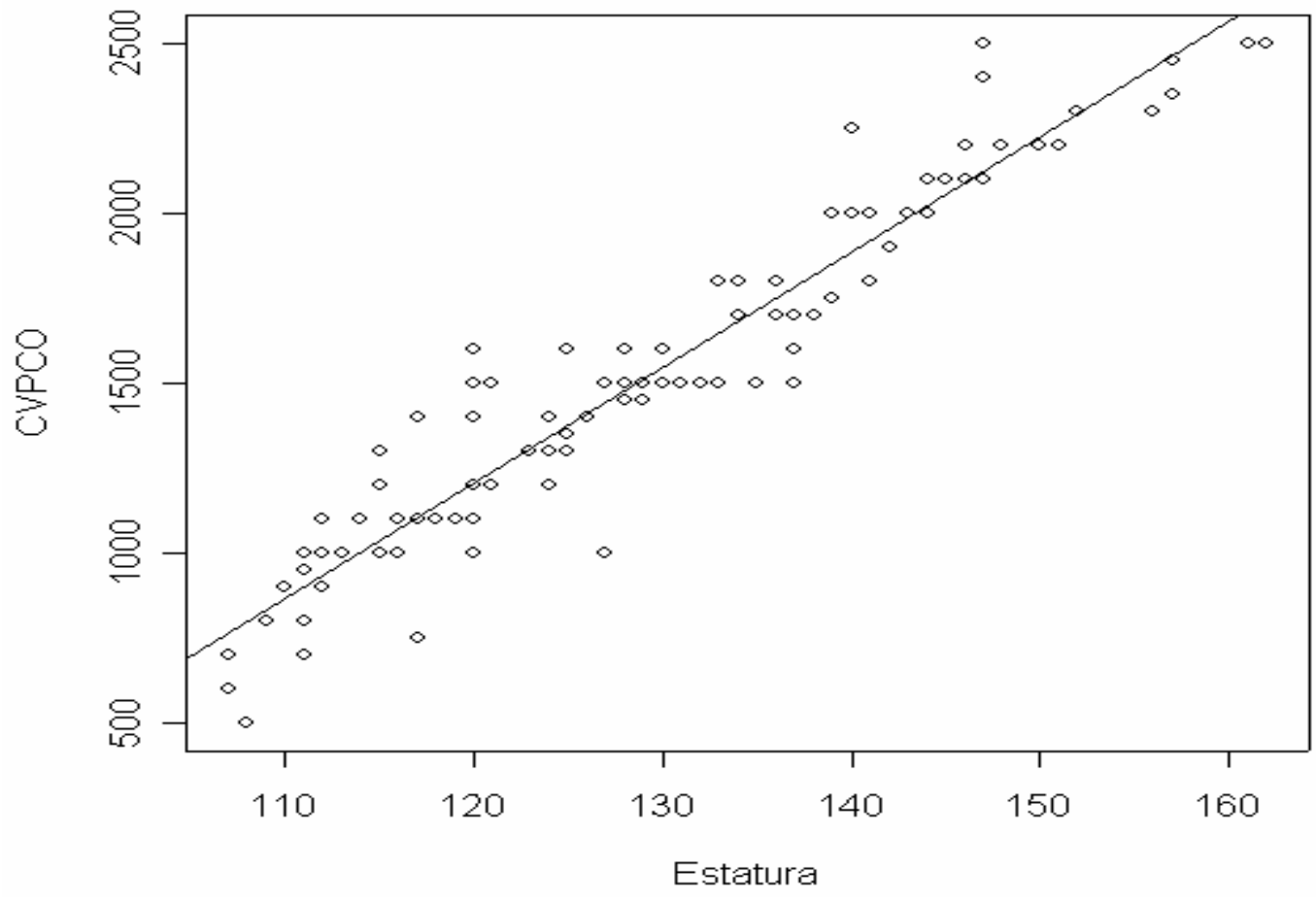

* Height in cm. CVPCO= vital capacity with nasal occlusion. 
TABLE 2. Average phonation time of vowels and consonants of all subjects according to the sex and age*.

\begin{tabular}{ccccccccccc}
\hline Age & \multicolumn{2}{c}{$/ \mathrm{a} /(\mathrm{sec})$} & \multicolumn{2}{c}{$/ \mathrm{i} /(\mathrm{sec})$} & \multicolumn{2}{c}{$/ \mathrm{u} /(\mathrm{sec})$} & \multicolumn{2}{c}{$/ \mathrm{s} /(\mathrm{sec})$} & \multicolumn{2}{c}{$/ \mathrm{z} /(\mathrm{sec})$} \\
\hline & $\mathrm{M}$ & $\mathrm{F}$ & $\mathrm{M}$ & $\mathrm{F}$ & $\mathrm{M}$ & $\mathrm{F}$ & $\mathrm{M}$ & $\mathrm{F}$ & $\mathrm{M}$ & $\mathrm{F}$ \\
4 & 4,88 & 5,39 & 3,82 & 5,43 & 4,46 & 5,77 & 4,07 & 3,66 & 3,32 & 3,91 \\
5 & 6,25 & 5,62 & 6,89 & 6,84 & 6,45 & 5,92 & 5,39 & 4,17 & 5,58 & 5,02 \\
6 & 5,76 & 7,00 & 5,73 & 7,43 & 6,00 & 6,79 & 4,82 & 5,03 & 5,80 & 6,33 \\
7 & 8,93 & 11,65 & 8,89 & 9,62 & 8,33 & 11,00 & 6,89 & 6,26 & 7,66 & 7,46 \\
8 & 12,14 & 8,41 & 12,04 & 8,73 & 12,40 & 7,92 & 7,34 & 7,17 & 10,88 & 7,78 \\
9 & 9,60 & 9,51 & 7,93 & 10,61 & 9,67 & 10,30 & 6,67 & 8,61 & 9,43 & 8,61 \\
10 & 10,04 & 11,1 & 11,5 & 11,66 & 12,11 & 10,71 & 11,8 & 8,51 & 11,74 & 10,41 \\
Total average & 8,22 & 8,38 & 8,11 & 8,61 & 8,48 & 8,34 & 6,71 & 6,20 & 7,77 & 7,07 \\
\hline
\end{tabular}

* Age in years; phonation time of vowels and consonants in seconds.

TABLE 3. Average MPT measures of vowels and consonants and time of counting numbers related to the average height measures according to the age*.

\begin{tabular}{cccccccc}
\hline Age & Height & /a/ & /i/ & /u/ & $/ \mathrm{s} /$ & $/ \mathrm{z} /$ & NUM \\
\hline 4 & 112,77 & 5,23 & 5,85 & 5,59 & 4,74 & 5,08 & 5,12 \\
5 & 115,54 & 6,00 & 7,29 & 7,16 & 5,74 & 6,42 & 5,76 \\
6 & 120,05 & 6,66 & 5,78 & 6,09 & 4,4 & 8,08 & 4,93 \\
7 & 127 & 9,71 & 9,08 & 8,87 & 6,37 & 7,48 & 8,46 \\
8 & 135,6 & 9,65 & 10,43 & 9,65 & 8,1 & 8,67 & 9,31 \\
9 & 141,47 & 9,53 & 10,5 & 10,15 & 8,15 & 9,77 & 9,61 \\
10 & 145,94 & 10,69 & 10,98 & 10,9 & 8,67 & 10,43 & 9,74 \\
\hline
\end{tabular}

* Age in years; height in cm; MPT measures in seconds. NUM = counting numbers.

TABLE 4. Average MPT measures of consonants and the ratio between the measures according to the age*.

\begin{tabular}{cccc}
\hline Age & $/ \mathrm{s} /$ & $/ \mathrm{z} /$ & Ratio s/z \\
\hline 4 & 4,74 & 5,08 & 0,93 \\
5 & 5,74 & 6,42 & 0,89 \\
6 & 4,4 & 8,08 & 0,54 \\
7 & 6,37 & 7,48 & 0,85 \\
8 & 8,1 & 8,67 & 0,93 \\
9 & 8,15 & 9,77 & 0,83 \\
10 & 8,67 & 10,43 & 0,83 \\
\hline
\end{tabular}

* Age in years; MPT in seconds.

TABLE 5. Averages, Standard deviation (SD) and the ratio between the results of Simple and Composed Phonic Quotient from 4 to 10 years old*.

\begin{tabular}{cccccc}
\hline \multirow{2}{*}{ Age } & \multicolumn{2}{c}{ SPQ } & \multicolumn{2}{c}{ CPQ } & Ratio \\
\cline { 2 - 4 } & average & SD & average & SD & CFS/CFC \\
\hline 4 & 207,92 & 92,15 & 223,52 & 89,38 & 0,930208 \\
5 & 208,81 & 63,83 & 210,79 & 49,57 & 0,990607 \\
6 & 208,31 & 71,81 & 207,76 & 41,65 & 1,002647 \\
7 & 158,02 & 64,16 & 174,42 & 39,67 & 0,905974 \\
8 & 188,25 & 61,18 & 190,42 & 42,75 & 0,988604 \\
9 & 241,87 & 82,16 & 222,69 & 47,32 & 1,086129 \\
10 & 218,50 & 57,51 & 201,33 & 41,11 & 1,085283 \\
\hline
\end{tabular}

* Idade em anos, CFS = Cociente fônico simples; CFC = cociente fônico composto. 


\section{Discussion}

The respiratory dynamics measures are important in the speech-language clinic either as a parameter of children's phonation conditions, or as a therapeutic follow up in cases of speechlanguage or respiratory pathology.

Concerning the VC findings, there was an increase of the values with the increase of children's age and the subsequent growth of height. In the studied age group there was a great growth of the children's physical structure (107 to $162 \mathrm{~cm}$ height). Thus, the continuing growth of the physical structure, and consequently the increase of the VC is expected during adolescence and adult phases. These findings re-affirm the values published in the Spirometry Consensus (SOCIEDADE...,1996).

The mean values of VC found in this sample are close to the ones mentioned by Zemlin (2000), stressing the proximity of the age groups between these studies. It should be considered that besides the height, the age might influence these measures, and there might be a sudden increase of the values during adolescence, once in this phase the height increases a lot.

In the Brazilian speech-language practice, the VC measures are obtained with the spirometer FAMI-ITÁ $^{\circ}$. In the specialized literature, no data regarding the $\mathrm{VC}$ in children measured with this instrument was found. It is possible to find spirometry data obtained by computerized programs (Eigen et al, 2001; Jones et al, 2000).

Comparing the $\mathrm{VC}$ data of this research with the ones from the standard measures table of the spirometer FAMI-ITÁ ${ }^{\mathrm{O}}$, the children from the sample reached great results.

Observing the average $\mathrm{VC}$ measures in the different ways of the test (with and without nasal occlusion, standing and sitting down), very close values are noticed suggesting that in this sample this variation was not determinant for a change in the final values of $\mathrm{VC}$ measures.

The sustained phonation measures of vowels presented in the literature vary greatly. Nevertheless, in general the mean values presented by other researches are from 10 to 12 seconds, varying according to the sex and the height.

In this research, the averages of the measures of all subjects of the sample were around 8 seconds in all vowels and did not vary according to the sex. These values were below the ones presented by the literature, however it should be considered that this sample included four-year-old children and this could be a determinant factor. Analyzing the mean phonation time of vowels, between boys and girls at ten years of age, a variation from 10,04 to 12,11 seconds is observed, not being determinant regarding the sex.

Comparing the result of this research with another study with Brazilian children (Rockenbach; Feijó, 2000), it is verified very similar MPT of vowels only for the female sex; for male, the values of this research were until 3 seconds lower. This difference of values for male is observed because there was no difference among the male and female in this research.

It is also interesting to note that the maximum values of MPT of vowels in this research were around 21 seconds and close to the highest values reported in the literature (Wilson, 1993). The great MPT variation found in this study and in several bibliographic references indicates the necessity of other studies to raise the possible interferences in these measures changes. A hypothesis is the vocal characteristics of different languages speaking individuals. In Brazil, for example, a more breathy voice that favors a higher consume of the exhaled air during phonation is culturally accepted.

The MPT of the consonants /s/ and /z/ presented results closer to the vowels ones, but with a decrease of 1,5 seconds at the most, and the /z/ values were higher than the /s/ values. This fact may be explained by the difference in the use of articulators in the vowels and fricative consonants production. The possibility of using the expiratory flux raises in the emission of fricative sounds, which induces to a decreasing in the sustaining of the sound after an inspiration. Besides the difference between the production of the two consonants: the participation of the glottal source in the phoneme /z/ emission.

The MPT values for consonants varied according to the children's age, with averages of $8,67 \mathrm{sec}$. for / $\mathrm{s} /$ and of $10,43 \mathrm{sec}$ for /z/, at ten years of age. Comparing to the studied literature, similar values are found in the age group of four to five years old (Frey, 1978, apud Wilson, 1993). Nevertheless, in the other studied age groups these values present higher and higher differences, and at ten years of age it is observed the highest difference (Tait et al, 1980). The values presented by Rockenbach and Feijó (2000) are higher. However, in the age group of six to eight years old this difference is not as significant as in the age 
group of nine to ten years old, that reached 4 seconds; this did not occur only in the measures of phoneme /z/ when data were separated according to the sex, which for male was 7,91 seconds and in this study it was 8,11 .

In this sample no difference was found between the mean MPT measures of consonants regarding the sex. The measures got higher with the age increase, corroborating Hersan's study (2003) and the Spirometry Consensus (SOCIEDADE...,1996), and with the children's height increase. This fact is related to the height and the pulmonary capacity increase as observed in the VC results. The average measures of all group were not different concerning the subjects' sex.

Analyzing the possible causes for the differences between the researches mentioned above, the methodological difference, the biological and socio-economic differences might be considered as hypotheses. Children from this study are public school students and many of them are located in peripherical areas of Marília city. These children did not practice any sports consistently, only the physical education classes at school. Rockenbach and Feijó (2000) reported differences in some measures of respiratory measures between children of private and public schools. It is known that nowadays in Brazil there is a difference in the socio-economic and cultural situation between students from public and from private schools. However, there are no research data that could support this affirmation; this kind of study would be important.

The phonation time measures of consonants / $\mathrm{s} /$ and / $\mathrm{z} /$ are used in the speech-language clinic as a way to analyze the glottal efficiency through the ratio between them. The values found in this study were similar to the ones mentioned in the literature.

The MPT measures of counting numbers were obtained as a way to represent a sequenced speech, such as in a conversation. This measure parameter is important to observe how the inspired air is used during the sequenced speech. The values found increased among the age groups, beginning in 5,12 sec and reaching 9,74 sec. All values were close to the MPT of vowels and consonants, nevertheless, they were lower at ten years of age. This data points out to the hypothesis that children maintain a constant respiratory flux use in the production of the speech sounds, either in the sustaining of certain phonemes as in the emission of sequenced words. Despite being a common test in the speechlanguage practice in Brazil, no data that could be compared to the ones found in this research with the same age groups were found in the national and international literature.

The SPQ and CPQ values presented similar averages in all age groups, varying from 158,02 ml/ séc at seven years to $241,87 \mathrm{ml} / \mathrm{sec}$ at nine years and the total average was $204,52 \mathrm{ml} / \mathrm{sec}$. In the studied literature, a few results were found for this measure.

As the SPQ analysis is a relation between other measures, the differences found in this research may be directly related to the MPTs. Concerning the $\mathrm{VC}$, the values found in this research are similar to the some mentioned in the literature. There were differences when the samples were different, specially regarding the height. Nevertheless, the MPT values, in general, were below the ones presented in the literature, which explains the higher phonic quotient values, once if children presented a good VC measure, that is, pulmonary flux potential, the phonation time measures could be a little higher reducing, consequently, the SPQ values. However, as these studies are limited in the literature, other studies would be important to survey the Standard measures in Brazilian children.

The CPQ also informs about the expiratory air use in the phonation, specially in conversational situations. The mean values found were between $174,42 \mathrm{ml} / \mathrm{sec}$ and $223,52 \mathrm{ml} / \mathrm{sec}$, and the general average was $204,41 \mathrm{ml} / \mathrm{sec}$. This result is very similar to the SPQ.

The ratio between the SPQ and the CPQ, close to one, indicates the same use of the pulmonary function, either in the sustained emission or in the conversation.

It may be inferred that children from this sample presented good phonation quality, using a good glottal adjustment.

Data obtained in this research are important for the knowledge of respiratory dynamics measures in a school children sample. Other studies with the same age group should be developed in order to provide a representative sample of the Brazilian reality, once these tests are widely used in the speech-language clinic quotidian.

\section{Conclusion}

After the analysis of all tests used for the survey of respiratory dynamics measures in nasal breathing children, it might be concluded that children from this sample presented good VC values, and children's age and height were determinant factors for these measures' values.

Another very important finding was the 
proximity between the values of the different ways of $\mathrm{VC}$ collecting. In this sample, in which children could not have a respiratory mode disorder, data confirmed the integrity of the pulmonary capacity and of the expiratory control, including the velofaryngeal muscles.

The respiratory dynamics tests are commonly used in the speech-language clinic, however studies of this nature with children are not easily found in the literature and the ones published present some of the possible tests that can be used in a more complete evaluation. As these data are scarce in the literature, frequently the respiratory dynamics tests are used more as a therapeutic

\section{References}

AGABA, P. A.; THACHER, T. D.; ANGYO, I. A.; AGABA, E. I. Peak expiratory flow rates in healthy nigerian children. J. Trop. Pediatr., London, v. 49, n. 3, p. 157159, june 2003.

BEHLAU, M.; MADAZIO, G.; FEIJÓ, D.; AZEVEDO, R.; GIELOW, I.; REHDER, M. I. Aperfeiçoamento vocal e tratamento fonoaudiológico das disfonias. In: BEHLAU, M. (Org.). Voz: o livro do especialista. Rio de Janeiro: Revinter, 2005. v. 2, cap. 13, p. 409-564.

DOMÉNECH-CLAR, R.; LÓPEZ-ANDREU, J. A.; COMPTE-TORRERO, L.; DE DIEGO-DAMIÁ, A.; MACIÁN-GISBERT, V.; PERPIÑÁ-TORDERA, M.; ROQUÉS-SERRADILLA, J. M. Maximal static respiratory pressures in children and adolescents. Pediatr. Pulmonol., New York, v. 35, n. 5, p. 126-132, feb. 2003.

DUGDALE, A. E.; MOERI, M. Normal values of forced vital capacity (FVC), forced expiratory volume (FEV) e peak flow rate (PFR) in children. Arch. Dis. Childh., London, v. 43, n. 228, p. 229-234, apr. 1968.

EIGEN, H.; BIELER, H.; GRANT, D.; CHRISTOPH, K.; TERRILL, D.; HEILMAN, D. K.; AMBROSIUS, W. T.; TEPPER, R. S. Spirometric pulmonary function in healthy preschool children. Am. J. Resp. Crit. Care Med., New York, v. 163, n. 3, p. 619-623, mar. 2001. parte 1.

ENRIGHT, P. L.; LINN, W. S.; AVOL, E. L.; MARGOLIS, H. G.; GONG JR, H.; PETERS, J. M. Quality of spirometry test performance in children and adolescents: experience in a large field study. Chest., Chicago, v. 118, n. 3, p. 665671,2000

FREY, M. The prolongation of /s/ and /z/ by pre-school children. Indiana University, 1978. Unpublishing. apud: WILSON, D. K. Problemas de voz em crianças. São Paulo: Manole, 1993.

HERNANDO, S. V.; GARCIA-MARCOS, L.; GOMEZ, G. J.; FAURA, M. U.; RUBIO, P. J.; NAVARRO, O. M. D.; HERNANDEZ, D. J. A. Peak expiratory flow rate in 4 to 15year-old children: comparison of 3 measuring models. Anal. Espan. Pediatr., Barcelona, v. 52, n. 4, p. 327-333, apr. 2000.

HERSAN, R. C. Disfonia na infância: abordagem fonoaudiológica. In: LOPES FILHO, O. Tratado de follow up, than as a initial evaluation in the clinical practice. Thus, there is no parameter for the comparison between normal and differentiated situations of the phonation system.

The results found in this research are important for the speech-language practice despite not being characterized as a study with normative data. However, it is the first study of this nature with the age group selected.

Other studies involving such measures with children from Sao Paulo are necessary for gathering normative data of this population in order compare them, either in clinical situations as in studies of this nature. otorrinolaringologia. São Paulo: Roca, 2003. v. 4, cap. 49, p. 546-558.

HUANG, G.; LIU, G.; HUANG, J. Study of peak expiratory flow in 728 normal adolescents in Chengdu area. J. West China, Chengdu, v. 32, n. 3, p. 427-429, sep. 2001.

JONES, M.; CASTILE, R.; DAVIS, S.; KISLING, J.; FILBRUN, D.; FLUCKE, R.; GOLDSTEIN, A.; EMSLEY, C.; AMBROSIUS, W.; TEPPER, R. S. Forced expiratory flows and volumes in infants. Am. J. Resp. Crit. Care Med., New York, v. 161, n. 2, p. 353-359, feb. 2000. (Normative data and lung growth).

PÉREZ-PADILLA, R.; REGALADO-PINEDA, J.; ROJAS, M.; CATALÁN, M.; MENDONZA, L.; ROJAS, R.; CHAPELA, R.; VILLALBA, J.; TORRES, V.; BORJAABURTO, V.; OLAIZ, G. Spirometric function in children of Mexico City compared to Mexican-American children. Pediatr. Pulmonol., New York, v. 35, n.3, p. 177-183, mar. 2003a.

PEREZ-PADILLA， R.; REGALADO-PINEDA，J.; MENDOZA, L.; ROJAS, R.; TORRES, V.; BORJAABURTO, V.; OLAIZ, G.; Empece study group: spirometric variability in a longitudinal study of school-age children. Chest, Chicago, v. 123, n. 4, p. 1090-1095, apr. 2003 b.

RAPPAPORT, E. B.; GILLILAND, F. D.; LINN, W. S.; GAUDERMAN, W. J. Impact of respiratory illness on expiratory flow rates in normal, asthmatic, and allergic children. Pediatr. Pulmonol., New York, v. 34, n. 2, p. 112-121, aug. 2002.

ROCKENBACH, S. P.; FEIJÓ, A. V. Estudo do tempo máximo de fonação em crianças de 6 a 10 anos de idade. Pró-Fono R. Atual. Cient., Carapicuíba (SP), v. 12, n. 2, p. 81-85, set. 2000.

SHIGEMORI, Y. Some tests related to the air usage during phonation. Clin. Investig. Otol., Fukuoka, n. 23, p. 138166, 1977.

SOCIEDADE BRASILEIRA DE PNEUMOLOGIA E TISIOLOGIA. I Consenso Brasileiro Sobre Espirometria, Jornal de Pneumologia, São Paulo, v. 22, n. 3, p. 130136, mai-jun.1996.

STEMPLE, J. C.; GLAZE, L. E.; KLABEN, B. G. Clinical 
voice pathology: theory and management. 3. ed. Canada: Singular, 2000. 544 p.

SUBBARAO, P.; LEBECQUE, P.; COREY, M.; COATES, A. L. Comparison of spirometric reference values. Pediatr. Pulmonol., New York, v. 37, n. 6, p. 515-522, jun. 2004.

TAIT, N. A.; MICHEL, J. F.; CARPENTER, M. A. Maximun duration of sustained $/ \mathrm{s} /$ and $/ \mathrm{z} /$ in children. J. Speech Hear. Dis., Danville, v. 45, n. 2, p. 239-246, may 1980.

TOMALAK, W.; POGORZELSKI, A.; PRUSAK, J. Normal values for maximal static inspiratory and expiratory pressures in healthy children. Pediatr. Pulmonol., New York, v. 34, n. 1, p. 42-46, jul. 2002.

TORRES, L. A. G. M. M.; MARTINEZ, F. E.; MANÇO, J. C. Correlation between standing height, sitting height, and arm span as an index of pulmonary function in 6 - 10- year-old children. Pediatr. Pulmonol., New York, v. 36, n. 3, p. 202-208, ago. 2003.

VIJAYAN, V. K.; REETHA, A. M.; KUPPURAO, K. V.; VENKATESAN, P.; THILAKAVATHY, S. Pulmonary function in normal south indian children aged 7 to 19 years. Indian J. Chest Dis. Allied Sci., Delhi, v. 42, n. 3, p. 147-156, jul.-sep. 2000.

WILSON, D. K. Problemas de voz em crianças. São Paulo: Manole, 1993.

ZAPLETAL, A.; CHALUPOVÁ, J. Forced expiratory parameters in healthy preschool children: 3-6 years of age. Pediatr. Pulmonol., New York, v. 35, n. 3, p. $200-$ 207, jan. 2003.

ZEMLIN, W. R. Princípios de anatomia e fisiologia em fonoaudiologia. Porto Alegre: Artmed, 2000. 